\title{
Meningeal vein and subarachnoid FLAIR hyperintensities in polycythaemia vera
}

\author{
Ioana Maria Ion, ${ }^{1}$ Eric Thouvenot, ${ }^{1,2}$ Marwane Cheriet, ${ }^{1}$ Dimitri Renard (D) ${ }^{1}$
}

${ }^{1}$ Neurology, CHU Nîmes, Hôpital Caremeau, Nîmes, France ${ }^{2}$ INSERM, IGF, Univ. Montpellier, CNRS, Montpellier, France

\section{Correspondence to} Professor Eric Thouvenot; eric.thouvenot@chu-nimes.fr

Accepted 25 January 2022
Check for updates

(C) BMJ Publishing Group Limited 2022. No commercial re-use. See rights and permissions. Published by BMJ.

To cite: Ion IM, Thouvenot $E$, Cheriet $\mathrm{M}$, et al. BMJ Case Rep 2022;15:e246655 doi:10.1136/bcr-2021246655

\section{DESCRIPTION}

A man in his fifties without medical history or cardiovascular risk factors presented with aquagenic pruritus since 3 months, fluctuating visual disturbance and headache since 1 week, followed by acute dysarthria and right-sided motor deficit. Clinical examination showed, in addition to dysarthria and right hemiparesis, facial erythrosis. MRI showed acute infarction in the left anterior choroidal artery territory, and bilateral vascular and subarachnoid fluid-attenuated inversion recovery (FLAIR) hyperintensities predominant in the posterior brain regions (figure 1). Perfusion weighted imaging (PWI) showed bilateral cortical-subcortical occipital perfusion deficit together with global cortical hypoperfusion. Blood analysis showed increased haematocrit value (70\%, normal 40\%-50\%), haemoglobin level (220g/L, normal 130-170g/L) and white cell count $\left(210 \times 10^{9} / \mathrm{L}\right.$, normal $3.9 \times 10^{9} / \mathrm{L}-$ $\left.10.9 \times 10^{9} / \mathrm{L}\right)$, and normal platelet count and erythropoietin level. Carotid doppler ultrasonography, ECG monitoring, transthoracic and transesophageal echocardiography, and cardiac MRI were all normal. A diagnosis of probable polycythaemia vera (PV) was made according to WHO diagnostic criteria. ${ }^{1}$

Visual symptoms, headache, pruritus and facial erythrosis rapidly improved after the start of treatment with repeated phlebotomy, hydration and acetylsalicylic acid $160 \mathrm{mg}$ once daily and hydroxycarbamide $500 \mathrm{mg}$ two times daily. One week later, haematocrit value was $56 \%$, haemoglobin level $17 \mathrm{~g} / \mathrm{dL}$, and white cell count $13700 / \mathrm{mm}^{3}$, and MRI showed disappearance of FLAIR vascular and subarachnoid hyperintensities. Genetic analysis showed a JAK2 V1617F

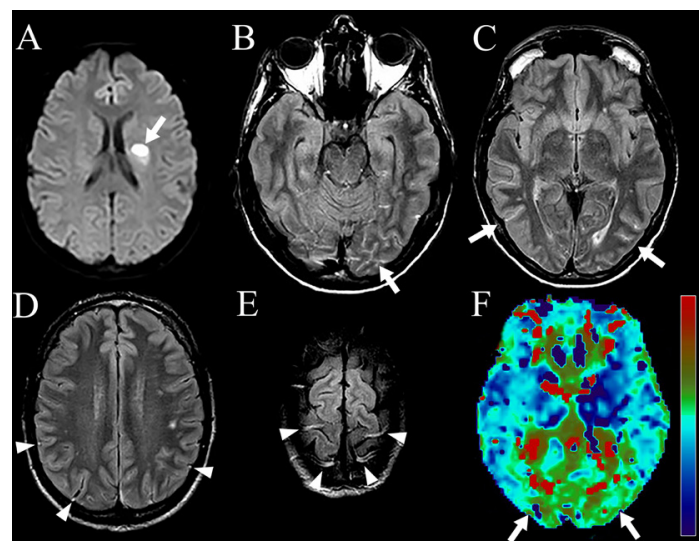

Figure 1 MRI showing (arrows) acute infarction on diffusion weighted imaging (DWI) $(A)$, bilateral subarachnoid $(B, C)$ and meningeal vein $(D$, E) hyperintensities on FLAIR, and bilateral occipital perfusion deficit (time-to-peak map, (F)). mutation. Six months later, the patient fully recovered from right hemiparesis while slight dysarthria persisted.

Risk factors for thrombosis in PV include increased haematocrit $(10 \%$ increase of haematocrit has been estimated to increase blood viscosity by $20 \%$ ) and elevated white $=$ cell count (ie, $>15000 / \mathrm{mm}^{3}$ ). PV can result in acute brain infarction in more than $15 \%$, probably related to increased blood viscosity, prothrombotic state (endothelial dysfunction and platelet activation are thought to be underlying mechanisms precipitating thrombus formation) and/ or microemboli. Increased density on CT of cerebral venous sinuses (correlating with haematocrit and haemoglobin levels) in PV patients have been reported in earlier studies. ${ }^{2-4}$

The reversible vascular and subarachnoid FLAIR hyperintensities observed in our PV patient were most likely related to low flow in the meningeal veins due to increased blood viscosity, whereas perfusion deficit was attributed to venous congestion (related to reduced outflow, identical to earlier report observed in patients with cerebral venous thrombosis). ${ }^{5}$

\section{Patient's perspective}

I hope this publication will help young neurologists, radiologists and haematologists have a new perspective at my disease.

\section{Learning points}

Polycythaemia vera may be revealed by stroke due to increased blood viscosity, prothrombotic state and microemboli.

- Increased blood viscosity in polycythaemia vera may manifest as reversible (when treated) low flow in meningeal veins.

Contributors IMl: drafting/revising the manuscript, study concept or design, analysis or interpretation of data. ET: drafting/revising the manuscript, study concept or design. MC: analysis or interpretation of data. DR: drafting/revising the manuscript, study concept or design, analysis or interpretation of data.

Funding The authors have not declared a specific grant for this research from any funding agency in the public, commercial or not-for-profit sectors.

Competing interests None declared.

Patient consent for publication Consent obtained directly from patient(s).

Provenance and peer review Not commissioned; externally peer reviewed. 
Images in...

Case reports provide a valuable learning resource for the scientific community and can indicate areas of interest for future research. They should not be used in isolation to guide treatment choices or public health policy.

\section{ORCID iD}

Dimitri Renard http://orcid.org/0000-0002-3511-8151

\section{REFERENCES}

1 Arber DA, Orazi A, Hasserjian R, et al. The 2016 revision to the World Health Organization classification of myeloid neoplasms and acute leukemia. Blood 2016;127:2391-405.
2 Ben Salem D, Osseby GV, Rezaizadeh-Bourdariat K, et al. [Spontaneous hyperdense intracranial vessels seen on CT scan in polycythemia cases]. J Radiol 2003;84:605-8.

3 Gayathri S, Prasad A, Sachdeva N, et al. Unique features of polycythemia observed on plain non contrast CT scan of head. J Pediatr Neurosci 2010:5:27-9.

4 Healy JF, Nichols C. Polycythemia mimicking venous sinus thrombosis. AJNR Am J Neuroradiol 2002:23:1402-3.

5 Makkat S, Stadnik T, Peeters E, et al. Pathogenesis of venous stroke: evaluation with diffusion- and perfusion-weighted MRI. J Stroke Cerebrovasc Dis 2003:12:132-6.

Copyright 2022 BMJ Publishing Group. All rights reserved. For permission to reuse any of this content visit

https://www.bmj.com/company/products-services/rights-and-licensing/permissions/

BMJ Case Report Fellows may re-use this article for personal use and teaching without any further permission.

Become a Fellow of BMJ Case Reports today and you can:

- Submit as many cases as you like

- Enjoy fast sympathetic peer review and rapid publication of accepted articles

- Access all the published articles

Re-use any of the published material for personal use and teaching without further permission

\section{Customer Service}

If you have any further queries about your subscription, please contact our customer services team on +44 (0) 2071111105 or via email at support@bmj.com.

Visit casereports.bmj.com for more articles like this and to become a Fellow 